\title{
Development of the musical thinking of the beginner pianists
}

\author{
Krasimira Georgieva Fileva-Ruseva \\ Faculty of Music Pedagogy, Academy of Music, Dance and Fine Arts - Plovdiv, Bulgaria, Europe
}

Email address:

krassyfilleva@abv.bg

\section{To cite this article:}

Krasimira Georgieva Fileva-Ruseva. Development of the Musical Thinking of the Beginner Pianists. International Journal of Literature and Arts. Vol. 1, No. 3, 2013, pp. 26-30. doi: 10.11648/j.ijla.20130103.11

\begin{abstract}
Thinking is manifested by the speech. Through the semantic content of the speech entities, interactions, interdependencies, etc. are expressed. These complex interrelationships, as a product of the human thinking in general, exist in the different languages. Therefore, the spoken language can be translated from one language to another, preserving and conveying the specific content. Unlike the spoken language, the musical language can not be translated. The musical thinking process occurs spontaneously, and the content is "rationalized" by the character of the emotional response, that triggers in the perceiver. By logical musical thinking is meant typical of a geographical area, ethnicity or style development of the melody. That development has no equivalent in other geographic areas, ethnicities and styles, and so the musical thought is untranslatable. Therefore, while training beginner pianist-performers, along with other necessary qualities and skills, is essential to cultivate also the ability to empathy the expressed through the music feelings and the sense of distinctiveness of the different types of melodic structures. The ability to detect the underlying feelings in the work is achieved through different pedagogical approaches, such as: - The selection of an appropriate musical illustration to a short story, thought up by the teacher. - The recreation of the emotional meaning of the piece that is studied or played through created by the student tale, short story, verse or drawing. - The description of what he would draw to illustrate the music that has sounded. Using these methods "the understanding" of the emotional content of the musical work is encouraged - a necessary condition for improving the impact of the student's own interpretation or the adequate assessment of someone else's performance. The main method to form the sense of distinctiveness of the musical thought is the selection of a diverse repertoire for mastering. Other suitable approaches are: - Selecting an appropriate conclusion of the melody from several proposed cadences. Composing a logical conclusion of a melody by the student himself/herself. - Finishing of two different in character melodies. - Continuing the melody on a given small element of it. Thus accumulated and constantly enriched fund of musical-auditory notions, is of great benefit for both the more effective memorizing of the mastered piece, and the deeper understanding of the musical punctuation, syntax and the specificity of the musical image.
\end{abstract}

Keywords: Musical Thinking, Initial Training of Young Pianists, Musical-Auditory Notions, Musical-Auditory Experience

\section{Introduction}

The musical perception, the musical notions, the musical memory are psychic processes extensively studied by the psychologists and the music pedagogues. For example, many studies are being focused on the development of the musical memory in the piano education, resulting in the creation of various publications. The musical thinking, however, is a process which has not yet been studied in detail.

Thinking - "a complex process of a mediated cognition, achieved through analysis and synthesis, abstraction and summarization" [7, p 113] is based on simpler "trigger" psychic processes such as perception, notions, memory. Thinking is manifested by the speech. In the encoding process of the thought through speech, and in the decoding - the understanding of the thought, is developed the mental process itself.

The speech, through which are expressed thoughts and is shared information, has its phonic aspect (informative as far as on it can be deduced the ethnicity of those, who has pronounced the words sounded), but more important is the meaning. Through the semantic content of speech are expressed entities, interactions, interdependencies and etc. 
These complex interrelationships, as a product of the human thinking in general, exist in the different languages. Therefore the spoken language can be translated from one language to another, preserving and conveying the specific content.

Unlike the spoken language, the musical language can not be translated. It contains the musical thought - a melody that basically expresses feelings. Because of this the thinking process occurs spontaneously, i.e. is not subjected to the familiar mental operations, such as comparison, abstraction, generalization. Leading force in the musical thinking is the phonic - the ideal is beautiful and influent sounding, and the content is "rationalized" by the character of the emotional response that triggers in the perceiver. Since:

1) The nuance of this response is individual;

2) By logical musical thinking is meant typical of a geographical area, ethnicity or style development of the melody;

3) This development has no equivalent in other geographic areas, ethnicities and styles, and so the musical thought is untranslatable. Therefore, while training beginner musical performers (here I will talk only about education of pianists), along with other necessary qualities and skills, is essential to cultivate also the ability to empathy the expressed through the music feelings and the sense of distinctiveness of the different types of melodic structures.

\section{Developing Approaches}

\subsection{Developing the Ability to Empathy the Expressed through the Music feelings}

The ability to detect the underlying feelings in the work is achieved through different pedagogical approaches, such as:

\subsubsection{To Select an Appropriate Musical Illustration to a Short story, thought up by the Teacher}

The student needs to choose it amongst several suggested small clavier pieces (such as "Andersen's fairy tales" by S. Bortkievich).

\subsubsection{To Express the Emotional Meaning of the Studied or Performed Specifically for the Purpose by the Pedagogue Piece, through Created by the Student Tale, Short Story, Verse or Drawing}

For understanding the emotional content of a musical piece is appropriate also the following approach - the emotional meaning of the studied or played specifically for the purpose by the pedagogue piece, to be recreated through created by the student tale, short story, verse or drawing. This is a recoding of the musical information, using another encoding system - another art, but is it not an accurate "translation", as it is not "translated" and the specific event that has evoked the feelings, which permeate the musical miniature, cannot possibly be translated exactly.
Using the sign system of the preferred art, each student "translates" his/her own emotions, depicting an event, based on life experiences, which evokes in him/her similar feelings.

\subsubsection{To Describe What He Would Draw to Illustrate the Music that has Sounded}

Support may be sought in both the verbal and the visual arts - by asking the child to describe what he would draw to illustrate the music, which has sounded. The pedagogue should evaluate which of the listed educational techniques would be most appropriate in the particular lesson and to the individual abilities of the specific student, but also the fact that, especially in childhood, the variety of tasks is of great benefit to the process of training, needs to be taken into consideration.

Using these methods "the understanding" of the emotional content of the musical work is encouraged - a necessary condition for improving the impact of the student's own interpretation or the adequate assessment of someone else's performance. These pedagogical approaches are appropriate for the initial training of young pianists, regardless of whether in the future they would be prepared for professional musicians or would be educated and sensitive connoisseurs of the musical art.

The musical thinking is primarily due to the existence of musical-auditory experience. Moreover, the musical-auditory notions, gradually acquired during the education, that are constituting the musical-auditory experience, should be developed through perception, reproduction and memorizing of musical thoughts, that reflect different intonational styles and a variety of genres (as structure), as well as various emotional and notional components (as content). The musical thought consists of short intonational cores (corresponding to the words of the spoken language), including several tones. These tones, however, are in a specific modal structure (defined interval construction) and modal connections - relations. The musical thought is shaped also metrorhytmically. Furthermore, the succession of the tones in the musical core confines to the musical logic of a particular intonational style, i.e. it could not be found as a constructive element of a basically different intonational style.

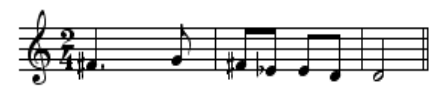

Figure 1

This musical core may be present in the melodies of Bulgarian and Turkish folklore songs but it is not inherent in the German, French, English folk music. The specified musical core, except that suggests a specific modal structure, also determines the corresponding metrorhythmical organization. This determination leaves its imprint on the character of the future development and directs the musical thought in the continuation, the deployment of the melody to adhere to the rules of the style 
of logical, acceptable, typical, new, original, etc. What guides and directs the thought further, is the musical-auditory experience that the individual has. The very nascency of the intonational core, that plays the role of a "trigger" - the initial musical thought is dependent on what sounds in "the musical mind" of "the one who has expressed" this musical thought - the creator of the melodic core. This defines an important direction both in the musical pedagogy in general, and particularly in the piano education - the musical material, provided for learning by the little pianist should be selected in a way that enables expansion of the "musical horizon", i.e. inclusion of a variety of tonal works in style and genre, and, as clarified above - in national specificity.

\subsection{Developing the Sense of Distinctiveness of the Different Types of Melodic Structures}

\subsubsection{Selecting a Various Repertoire}

The selection of a diverse repertoire is the main method to form the sense of distinctiveness of the musical thought the melody, and more broadly - of the very musical image that the little artist should perform.

\subsubsection{Finishing a Melody}

In order to allow the musical thought not only to be expressed, but also to be completed logically - according to the rules of the particular intonational style, i.e. the sense of distinctiveness of the melody to get a more specific outline in the mind of the learner, several variants of the exercise of "finishing" a melody, or of creating a musical conclusion are appropriate. The melodic cadence (the conclusion of the melody) is also an element of the specific, of the distinctive of a particular intonational style and is determined by the criteria eligible-ineligible, characteristic - uncharacteristic, stylistically consistent - inconsistent. This means that in order to form an opinion on how the conclusion of the melody should sound logically, the student should trace the logic of the specified part. With such tasks the learning process of the beginner pianists may be diversified.

1) If the student has a fund of musical-auditory notions (illustrations) for an intonational style rich enough, the teacher can give the task of selecting an appropriate conclusion of the melody from several proposed cadences. It is appropriate, especially in the first attempts, the melodies - the object of the selection, to be sung, which facilitates the conduct of the exercise.
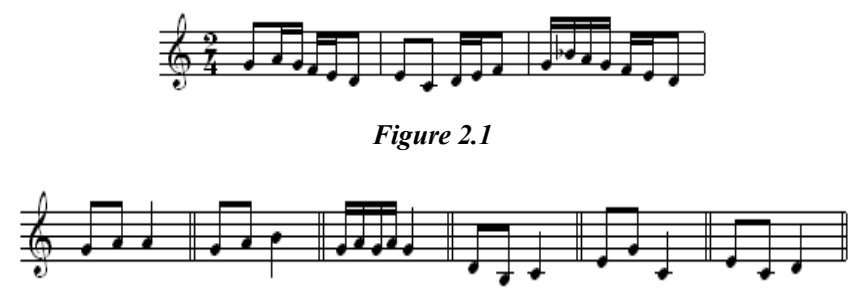

(a)

(b)

(c)

(d)

(e)

(f)
Naturally, it is necessary to test how the melody-task sounds with each one of the conclusions in order to assess that the most appropriate is the last one. In the Bulgarian musical folklore the Aeolian mode (the modal structure of the cited melody) is a common sound line, and the cadence including a subbase tone (the seventh scale degree in the medieval modes, in most of which, because of the second between it and the first scale degree, it doesn't possess the instability characteristic of the leading tone in the classic major and minor) is typical. This exercise stimulates the musical thought in the direction of a logical construction of a melody.

2) The task is further complicated in cases where the student has to compose himself/herself, based on his/her personal musical-auditory experience, a logical conclusion of a melody. This variant of the exercise is also conducted through singing, in order not to embarrass the student in finding the necessary tonal names (the encoding of the musical thought is performed by the teacher). Herein, a specific activation of the musical thinking is needed through the creation of his/her own, but logically appropriate conclusion:

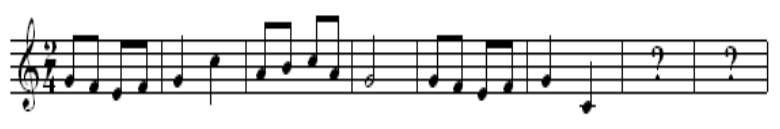

Figure 3

The teacher accepts or rejects the composed cadence. After the successful completion of the task, it may be requested also to find the tones on the piano (which implies active mental operations), to play the sound line, which the melody is built on, and then - the melody itself. The mental processes, preceding the successful playing of the finished melody are:

- Analyzing the melody, in which the distinctive features in its construction would be searched;

- Detecting the direction of the melodic movement (horizontal, ascending - conjunct or disjunct, descending conjunct or disjunct);

- Finding the corresponding keys on the piano.

- Complying with the metrorhytmical organization.

The successful managing can be used as a new task - to search the solution of several "instrumental" problems, such as fingering, as well as the problems, concerning the musical content - appropriate to the character of the melody technique marks and dynamics.

3) The finishing of two different in character melodies may be requested, in which inevitably is activated also the comparison of both of the emotional contents:

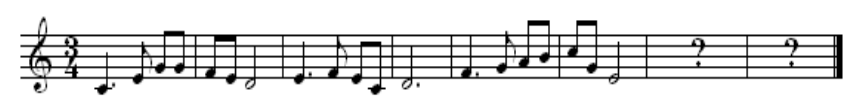

Figure 4.1

Figure 2.2 


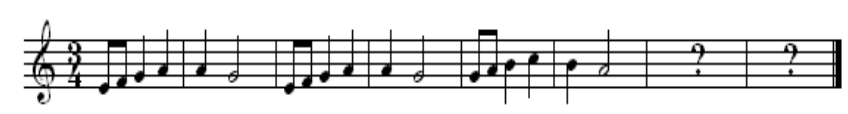

Figure 4.2

Whereas the suitable conclusions of the first melody are:

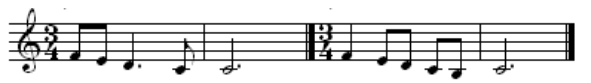

(a)

(b)

Figure 4.3

and the inappropriate one is:

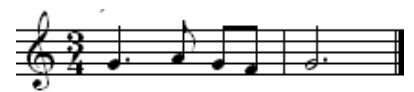

(c)

Figure 4.4

The second melody is appropriate to be completed:

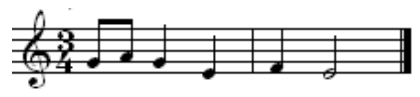

(a)

Figure 4.5

and inappropriate:

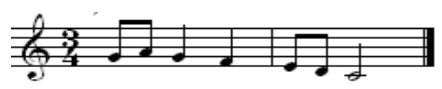

(b)

Figure 4.6

In order to be realized, to be memorized permanently and to be used more appropriately in the future learning, the auditory notions, the explanation-knowledge should be present, too: "The first melody is in natural (classic) major, in the conclusion it is appropriate to be present the supertonic and subtonic scale degrees. The second melody is in Phrygian minor, it sounds softer, more elegiac and the characteristic of the Phrygian mode interval minor second between I and II scale degrees, that would highlight the softness and tenderness of the melody, in the conclusion should be emphasized, i.e. the melodic movement II - I is suitable. Through this information sound notion is supplemented, specified and realized clearly. Thereafter the melody can be "found" on the piano, and from there on - be tested its interval correlations also from another initial tone. This points to the discovery of the fingering, applicable to the new key signature. It is appropriate that dynamics and articulation, reflecting the character of the melody would be sought again, as on the one hand, the recreation of the personality of the imagery with the available performer's means of expression is a problem that the interpreter would solve for any musical composition on which he/she would work, and on the other - thus knowledge about the emotional meaning of the possible applications of the performer's means of expression and their combination is accumulated, i.e. the artistic experience of the little pianist is enriched.

1) Particularly effective is the continuation of the melody by the student on a given small element of it. In this case, the student receives information also about the musical syntax, the construction of the musical sentence:

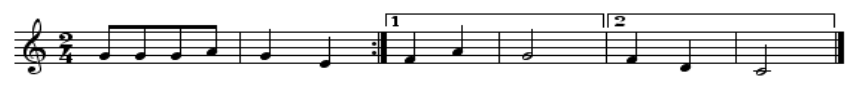

(a) Given

(b) May be continued

Figure 5

i.e. very often the second part to the musical thought begins in the same manner as the first, but changes in the end in order to sound complete (i.e. a period with a repeated construction). This is an often used structure of a musical thought.

By the more capable pupils these tasks can be solved directly by playing on the piano, without the preparatory stage - singing (in which the musical-auditory experience was used, but without encoding the melody by the tone names).

Thus accumulated and constantly enriched fund of musical-auditory notions, as well as the constant building of the sense of logical continuation of the musical thought (compared to the characteristics of the "trigger" - the beginning of each musical theme) is of great benefit for both the more effective memorizing of the mastered play, and the deeper understanding of the musical punctuation, syntax and the specificity of the musical image, intended by the tone artist. This is an important step towards its proper performing and the fine sense of distinctiveness, which is developed through these forms of teaching, also contributes to the more subtle and detailed understanding the individual features of the artistic style of the composer. This ability in the long term is beneficial for the musical erudition of the pianist.

\section{References}

[1] Алексеев, Александр. Интерпретация музыкальных произведений. На основе анализа искусства выдающихся пианистов XX века. М, 1984.

[2] Браудо, И. Артикуляция. О произношении мелодии. Под ред. Х. С. Кушнарова. Л, 1973.

[3] Голубовская, Н. О. О музыкальном исполнительстве. Л. 1985.

[4] Гофман, Й. - Фортепианная игра. Ответы на вопросы о фортепианной игре. М. 1961.

[5] Минчев, Б. Лекции по обща психология. София, 1993, p. 163. 
[6] Михел, Паул. Музикални способности и изпълнителски сръчности. Принос към музикалната психология. С. 1980 .
[7] Трифонов, Т. Обща психология. София, 2002, p. 232.

[8] Филева, К. В помощ на пианиста. Щрихи и темброви ефекти. Пловдив, 1998 